\title{
Evidence of Occult Hepatitis B Virus Infection among Omani Blood Donors: A Preliminary Study
}

\author{
Geraldine Kaminski Adel Alnaqdy Intesar Al-Belushi Jameel Nograles \\ Said H. Al-Dhahry \\ Departments of Microbiology and Immunology, College of Medicine and Health Sciences, \\ Sultan Qaboos University, Al-Khod, Oman
}

\section{Key Words}

Hepatitis B virus · Hepatitis B surface antigen •

Hepatitis B core antibodies - Omani blood donors

\begin{abstract}
Objectives: The aim of this study was to determine the prevalence of hepatitis B surface antigen (HBsAg), hepatitis $B$ core antibodies (anti-HBc) and hepatitis $B$ virus (HBV) DNA among a selected group of Omani blood donors. Materials and Methods: Two hundred HBsAg-negative donors were screened for anti-HBc. Those found to be positive were investigated for HBV DNA by polymerase chain reaction. HBsAg was retested on these sera following an immune complex dissociation technique. Results: HBsAg was present in $2.8 \%$ of the donors. Forty-one out of 200 (20.5\%) HBsAg-negative donors were positive for anti-HBc. Eleven were positive for HBsAg after dissociation, whereas 8 gave readings just over the cutoff. HBV DNA was not detected in this group. Conclusion: Findings indicate that testing donors for $\mathrm{HBsAg}$ alone is not sufficient to eliminate HBV from the blood supply in Oman.

Copyright $(2006$ S. Karger AG, Basel
\end{abstract}

\section{Introduction}

Hepatitis B virus (HBV) infects over 300 million individuals worldwide, resulting in over 250,000 deaths annually [1]. HBV can cause acute or chronic infections. Horizontal transmission mainly leads to acute infections, whereas vertical or perinatal infections generally result in chronicity [2-4].

Blood donors in Oman are routinely screened for hepatitis B surface antigen (HBsAg) as the method for reducing the risk of transfusion-transmitted HBV. Several studies have highlighted cases of HBV transmission in the absence of detectable HBsAg, particularly in the presence of antibody to hepatitis B core antigen (anti-HBc), a marker of previous contact with the virus [5-10]. Lack of detectable HBsAg in infectious blood may be due to a number of reasons such as coinfection with other viruses, for example hepatitis $\mathrm{C}$ virus ( $\mathrm{HCV}$ ), which may suppress HBsAg production [11-13], the presence of HBsAg at levels below the limit of detection of the assay, the presence of HBsAg mutants, particularly within the 'a determinant' region of the surface antigen, as is the case for the G145R mutant [14-16], and the formation of HBsAganti-HBsAg immune complexes in the sera resulting in

\section{KARGER}

Fax +4161306 1234 E-Mail karger@karger.ch www.karger.com 
the masking of the antigen [17]. Recipients of such blood products may be at risk of HBV infection.

Testing donations for anti-HBc antibodies, excluding those found to be positive, is not feasible in the Middle East where there is a high prevalence of anti$\mathrm{HBc}$ among the donating population and relatively few donors. Therefore, it has been suggested that eliminating only those donors with high titers of anti-HBc in areas with relatively high endemicity would contribute to transfusion safety without seriously affecting the blood supply [10].

The aims of this study were to (1) determine the frequency of HBsAg among blood donors attending the Sultan Qaboos University Hospital in Muscat (SQUH), (2) determine the prevalence of HBsAg-negative donors who are anti-HBc positive, and (3) to assess if the current strategy of testing blood for HBsAg only is sufficient to protect the blood supply in Oman from HBV.

\section{Materials and Methods}

\section{Donors and Viral Serology}

Serum samples from 200 consecutive blood donors collected at the blood bank in SQUH, which had been stored at $-20^{\circ} \mathrm{C}$ for up to 2 years, were investigated retrospectively. Sera from these donations had originally tested negative for $\mathrm{HBsAg}$, anti-HCV and antiHIV antibodies using the AxSYM ${ }^{\circledR}$ HBsAg, HCV and HIV microparticle enzyme immunoassays (Abbott Diagnostics, Wiesbaden, Germany). These sera were then tested for the presence of anti-HBc (AxSYM Core) as a marker of previous contact with HBV. Those found to be anti-HBc positive were assayed for antibody levels against HBsAg (anti-HBs) using the AxSYM Ausab test and also, when sufficient sera were available, for HBV DNA and HBV immune complexes. Those found to be anti-HBc negative showed no evidence of a past history of HBV infection and were regarded as negative controls for the HBV immune complex assay. Each immune complex run included a HBsAg-positive specimen. Attempts were made retrospectively to trace the recipients of donations found to contain HBV DNA and/or immune complex HBsAg.

\section{Immune Complex Dissociation}

HBsAg-anti-HBsAg immune complexes were dissociated according to the method described by Bernvil et al. [10]. Briefly, $75 \mu \mathrm{l}$ of serum was diluted in an equal volume of water and $75 \mu \mathrm{l}$ of $0.25 \mathrm{M}$ glycine ( $\mathrm{pH}$ 1.8) was added in a microtube. Following incubation at $37^{\circ} \mathrm{C}$ for $90 \mathrm{~min}$, a further $75 \mu \mathrm{l}$ of $1.5 \mathrm{M}$ Tris- $\mathrm{HCl}$ ( $\mathrm{pH}$ 7.4) was added and the reaction was then incubated for $2 \mathrm{~h}$ at $37^{\circ} \mathrm{C}$. The HBsAg levels were remeasured using the AxSYM. Those with readings greater than the assay cutoff ( 2 signal/negative readings, $\mathrm{S} / \mathrm{N}$ ) were determined positive.

\section{DNA Extraction}

DNA was extracted from $200 \mu$ l of serum using the Qiagen $(\mathrm{GmbH})$ QIAamp ${ }^{\circledR}$ DNA Mini Kit. The DNA was eluted in $50 \mu \mathrm{l}$ of water and stored at $-20^{\circ} \mathrm{C}$ until required.

Hepatitis B Virus Infection among Omani Donors

\section{HBV PCR}

Ten microliters of DNA extracts was used to amplify a segment of the core gene using a nested polymerase chain reaction (PCR) method described by Lindh et al. [18]. A seminested PCR reaction was also used to amplify DNA from the surface antigen gene using a modification of a technique described by Carman et al. [14]. The outer primers used for the surface gene were HBSU-1, GTATGTTGCCCGTTTGTCCTC, nucleotide position (nt) 459-479, and HBSU-2, ATACTTTCCAATCAATAGG, nt 988-970. The inner primers used were HBSU-1 and HBSU-3, GGCACTAGTAAACTGAGCCA, nt 687-667. Primers were custom made by Genset Singapore Biotech, Pte., Ltd., and are numbered from the unique EcoR1 site. The primary reaction was carried out in a volume of $50 \mu \mathrm{l}$ containing $20 \mathrm{pmol}$ of each primer, $1.5 \mathrm{mM} \mathrm{MgCl} 2,1 \times \mathrm{Taq}$ polymerase buffer, 1.25 units of Taq polymerase and $200 \mu M$ each dNTP (Promega, Madison, Wisc., USA). Two microliters of product from the first reaction was further amplified in a final volume of $25 \mu \mathrm{l}$ containing $20 \mathrm{pmol}$ of each primer with all other reagents at the same concentrations as described previously. Cycling parameters for the primary PCR were $94^{\circ} \mathrm{C}$ for 5 min followed by 35 cycles of $94^{\circ} \mathrm{C}$ for $1 \mathrm{~min}, 53^{\circ} \mathrm{C}$ for $1 \mathrm{~min}, 74^{\circ} \mathrm{C}$ for $1 \mathrm{~min}$ and a final $74^{\circ} \mathrm{C}$ for $7 \mathrm{~min}$. Parameters for the secondary reaction were $94^{\circ} \mathrm{C}$ for $3 \mathrm{~min}$ followed by 35 cycles of $94^{\circ} \mathrm{C}$ for $30 \mathrm{~s}, 50^{\circ} \mathrm{C}$ for $30 \mathrm{~s}$ and $74^{\circ} \mathrm{C}$ for $30 \mathrm{~s}$, with a final hold of $74^{\circ} \mathrm{C}$ for $7 \mathrm{~min}$. Products were held at $4^{\circ} \mathrm{C}$ prior to electrophoresis.

All PCR products were electrophoresed in 2\% agarose gels and viewed on a transilluminator. The images were captured using the Chemi Doc Imaging System (Biorad, USA).

\section{Results}

Data collected from the blood bank at SQUH showed that 3,290 donors were tested for HBsAg over a 1-year period and that the prevalence of HBsAg positivity among them was $2.8 \%$. Of the $200 \mathrm{HBsAg}$-negative donors randomly selected for this study, $41(20.5 \%)$ were found to be positive for anti-HBc. Of these, 37 (90.2\%) had detectable anti-HBs, including 22 with anti-HBs levels greater than $100 \mathrm{mIU} / \mathrm{ml}, 12$ with levels between 10 and $100 \mathrm{mIU} / \mathrm{ml}, 3$ with levels less than $10 \mathrm{mIU} / \mathrm{ml}$, and 4 had no anti-HBs at all. These accounted for 11, 6, 1.5 and $2 \%$ of the 200 donors assayed (fig. 1).

Anti-HBs and anti-HBc serology results are shown in table 1. The anti-HBc levels were reported by the AxSYM as signal/cutoff (s/co) and are expressed as the reciprocal, i.e. $1 /(\mathrm{s} / \mathrm{co})$. The levels ranged from 1.1 to 25 .

All 159 anti-HBc-negative donors were negative for HBsAg after dissociation $(\mathrm{S} / \mathrm{N}<2)$. All positive controls gave similar readings for HBsAg before and after dissociation. All anti-HBc-positive donors were originally negative for HBsAg, but following immune complex dissociation, eleven sera subsequently gave positive results for HBsAg. Positive readings of $2.0(\mathrm{~S} / \mathrm{N})$ were obtained for 
Fig. 1. Anti-HBc and anti-HBs status of 200 HBsAg-negative blood donations. Anti-HBc-positive donors are shown as a subsection of the larger diagram.

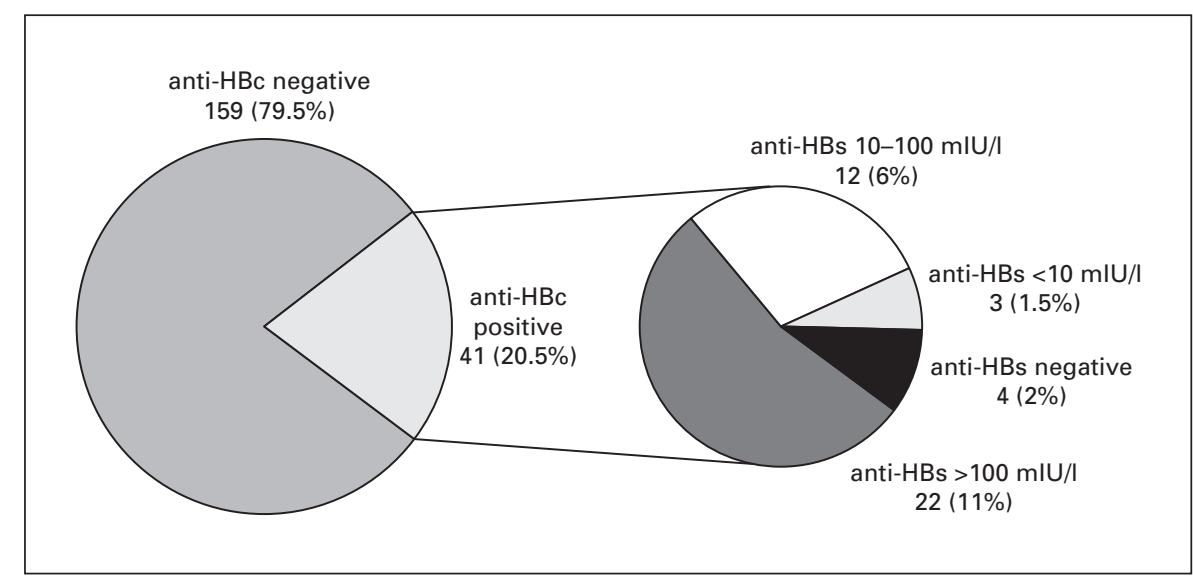

specimens No. 6, 11 and 16, readings of 2.1 for specimens No. 2, 19 and 22, and specimen No. 21 gave a reading of 2.7. Only donors No. 1,10 and 18 gave readings of $>3$, namely $6.3,127$ and 17.1 , respectively. There was insufficient serum from donor No. 29 for the HBsAg dissociation assay.

Sufficient serum for PCR analysis was available from donors No. 1 and 18 who were found to be positive for HBV DNA using core primers. One donor (No. 1) was also positive using primers directed against the surface gene. Donor No. 40, who was negative for HBsAg even after dissociation, was also positive for HBV DNA using the core primers but negative for the surface antigen PCR. Two specimens gave equivocal PCR results (donors No. 23 and 24) in that the original weak positive reaction with the core primers could not be reproduced either from the original DNA extract or from a fresh extract.

\section{Discussion}

This study indicates an HBsAg prevalence of 2.8\% among blood donors attending SQUH over the course of a year. Similar levels (3\%) have been reported among Saudi donors, while much lower levels $(0.1 \%$ average) have been found among European, Australian and US donors $[19,20]$.

While other countries have reported low levels of antiHBc among donors (UK 0.4\%, Denmark 0.7\%, France $1.3 \%$ and Germany $1.5 \%$ ), this study showed that $25 \%$ of blood donors had a history of HBV infection as indicated by the presence of anti-HBc [9,21-23]. It is possible that this is an overestimate as only one assay was used and false positives are possible [24]. Nevertheless, this is comparable with the anti-HBc prevalence of $16.4 \%$ when up to three different assays were employed in another study [12].

In this study, only 22 out of 41 donors with evidence of a past infection with HBV (anti-HBc-positive donors) had anti-HBs levels greater than $100 \mathrm{mIU} / \mathrm{ml}$, a level generally considered protective against HBV infection. Four out of 41 donors with past exposure to HBV did not have detectable antibodies to HBsAg. This latter group of 'anti$\mathrm{HBc}$ only' sera is of interest as they could indicate a long past infection or low-level chronic infection. Our investigation found only one of the four 'anti-HBc only' sera (donor No. 40) to contain detectable levels of HBV DNA.

Interestingly, although sera from donor No. 40 have been consistently negative for HBsAg and anti-HBs but positive for antibody to HBV antigen and anti-HBc over a 3-year period, HBV DNA encoding the core region and not the surface antigen region was only intermittently detected in these samples. This may be due to differences in sensitivity between the assays or it is possible that this donor harbors a mutant form of HBsAg, and further analysis using different primers for this area is required. Donor No. 41 gave a relatively high anti-HBs reading after dissociation, but no HBV DNA was detected. Again, this may be due to the sensitivity of the assay or the choice of primers.

Our results show that HBsAg was present as immune complexes in donors previously determined to be $\mathrm{HBsAg}$ negative. HBV DNA was found to be present in 2 donors (No. 1 and 18) when assayed by PCR for the core gene. One donor (No. 1) was also positive using the primers for the surface gene. Initial sequencing results of the surface 
Table 1. Anti-HBc, anti-HBs and post-dissociation $\mathrm{HBsAg}$ results of $41 \mathrm{HBsAg}$-negative anti-HBc-positive donors

\begin{tabular}{|c|c|c|c|c|}
\hline Donor & $\begin{array}{l}\text { anti-HBc } \\
1 /(\mathrm{s} / \mathrm{co})\end{array}$ & $\begin{array}{l}\text { anti-HBs } \\
\mathrm{mIU} / \mathrm{ml}\end{array}$ & $\begin{array}{l}\mathrm{HBsAg} \\
\text { (dissociated) } \\
\mathrm{S} / \mathrm{N}\end{array}$ & $\begin{array}{l}\text { HBV DNA } \\
\text { (core/surface) }\end{array}$ \\
\hline 1 & 13.70 & 1,050 & 6.3 & positive/positive \\
\hline 2 & 25.00 & 1,050 & 2.1 & negative/n.d. \\
\hline 3 & 19.60 & 1,050 & 1.8 & negative/n.d. \\
\hline 4 & 9.30 & 1,050 & 1.8 & insufficient \\
\hline 5 & 13.70 & 1,050 & 1.9 & negative/n.d. \\
\hline 6 & 13.30 & 1,050 & 2 & negative/n.d. \\
\hline 7 & 13.20 & 1,050 & 2.5 & negative/n.d. \\
\hline 8 & 16.90 & 744 & 1.7 & insufficient \\
\hline 9 & 3.60 & 646 & 1.9 & negative/n.d. \\
\hline 10 & 11.50 & 612 & 127 & insufficient \\
\hline 11 & 25.00 & 499 & 2 & negative/n.d. \\
\hline 12 & 11.80 & 442 & 1.8 & negative/n.d. \\
\hline 13 & 16.90 & 345 & 1.8 & negative/n.d. \\
\hline 14 & 11.80 & 301 & 1.8 & negative/n.d. \\
\hline 15 & 14.70 & 256 & 1.7 & negative/n.d. \\
\hline 16 & 2.30 & 250 & 2 & negative/n.d. \\
\hline 17 & 19.20 & 195 & 1.6 & insufficient \\
\hline 18 & 13.30 & 180 & 17.1 & positive/negative \\
\hline 19 & 9.10 & 165 & 2.1 & negative/n.d. \\
\hline 20 & 10.20 & 143 & 1.9 & negative/n.d. \\
\hline 21 & 14.90 & 120 & 2.7 & negative/n.d. \\
\hline 22 & 5.50 & 102 & 2.1 & negative/n.d. \\
\hline 23 & 7.30 & 92 & 1.4 & equivocal/n.d. \\
\hline 24 & 14.30 & 73 & 1.3 & equivocal/n.d. \\
\hline 25 & 16.40 & 68 & 1.3 & negative/n.d. \\
\hline 26 & 1.10 & 64 & 1.3 & negative/n.d. \\
\hline 27 & 5.40 & 38 & 1.3 & negative/n.d. \\
\hline 28 & 15.00 & 24 & 1.3 & negative/n.d. \\
\hline 29 & 14.50 & 24 & insufficient & negative/n.d. \\
\hline 30 & 16.00 & 23 & 1.5 & negative/n.d. \\
\hline 31 & 14.30 & 22 & 1.3 & negative/n.d. \\
\hline 32 & 13.10 & 21 & 1.2 & negative/n.d. \\
\hline 33 & 10.60 & 20 & 1.4 & negative/n.d. \\
\hline 34 & 14.10 & 16 & 1.4 & negative/n.d. \\
\hline 35 & 3.00 & 8.5 & 1.3 & negative/n.d. \\
\hline 36 & 12.30 & 7 & 1.3 & negative/n.d. \\
\hline 37 & 21.70 & 5 & 1.3 & negative/n.d. \\
\hline 38 & 18.50 & 0.6 & 1.4 & negative/n.d. \\
\hline 39 & 10.90 & 0.4 & 1.4 & negative/n.d. \\
\hline 40 & 16.10 & 0.2 & 1.3 & equivocal/n.d. \\
\hline 41 & 15.40 & 0.1 & 14 & negative/n.d. \\
\hline
\end{tabular}

n.d. = Not done.

amplicon of this donor have shown it to be serotype ayw/ genotype D (results not shown). It contained some mutations within the 'a determinant', but did not contain the G145R mutation. The amino acid sequence determined was identical to a previously published sequence (AF061524) isolated from an HBsAg-positive individual [25]. This suggests that the complex formation is host associated.

The finding of HBV DNA in the presence of high levels of anti-HBs in donor No. $1(>1,000 \mathrm{mIU} / \mathrm{ml})$ was unexpected. Previous investigators have reported similar results and it now appears that HBV serology is not as clear cut as was once thought and that the virus can be present for decades after the individual has serologically, biochemically and clinically recovered from an acute $\mathrm{HBV}$ infection. In these cases, HBV DNA has been found to be present at very low levels in the plasma $(<1,000$ cop$\mathrm{ies} / \mathrm{ml})[23,26,27]$. The ability of HBV to persist even in the presence of anti-HBs may be due to the virus being able to replicate in immunologically privileged sites.

There are conflicting reports about the infectivity of HBsAg-negative/HBV DNA-positive sera and further studies need to be done on recipients of these products $[23,28,29]$.

\section{Conclusion}

We have found an HBsAg prevalence of $2.8 \%$ among blood donors at SQUH. Rejecting those sera that are $\mathrm{HBsAg}$ negative/anti-HBc positive would result in a loss of almost a quarter of our donors. Results also show that the current method of testing donor sera for HBsAg is not sufficient to eliminate HBV from the blood supply in endemic areas such as Oman. The efficacy of PCR as a method of HBV detection is dependent on primer choice, as HBV DNA was not always positive for both the core and surface region. Immune complex dissociation of sera, either prior to testing or as an integral part of a commercial assay, will increase the detection rate of HBsAg-positive donations. This is strongly recommended where HBV prevalence is high at least in first-time donors. The use of nucleic acid testing on pooled sera is not recommended for HBV due to the possibility of low viral loads that may be involved. Individual testing would be required which is time-consuming and expensive. This study also highlights the need for close monitoring of transfusion recipients for HBV, irrespective of the antiHBs status of the donor, in cases where post-transfusion hepatitis is suspected.

Further investigations for HBV DNA and immune complex detection incorporating larger numbers are required to discover the full extent of $\mathrm{HBV}$ in the donor population of Oman. 


\section{References}

$\checkmark 1$ Kao JH, Chen DS: Global control of hepatitis B virus infection. Lancet Infect Dis 2002;2: 395-403.

2 Seeff LB, Beebe GW, Hoofnagle JH, Norman JE, Buskell-Bales Z, Waggoner JG, Kaplowitz N, Koff RS, Petrini JL Jr, Schiff ER, Shorey J, Stanley MM: A serologic follow-up of the 1942 epidemic of post-vaccination hepatitis in the United States Army. N Engl J Med 1987;16: 965-970.

-3 Stevens CE, Beasley RP, Tsui J, Lee WC: Vertical transmission of hepatitis B antigen in Taiwan. N Engl J Med 1975;292:771-774.

4 Okada K, Kamiyama I, Inomata M, Imai M, Miyakawa Y: e antigen and anti-e in the serum of asymptomatic carrier mothers as indicators of positive and negative transmission of hepatitis B virus to their infants. N Engl J Med 1976;294:746-749.

$>5$ Thiers V, Nakajima E, Kremsdorf D, Mack D, Schellekens H, Driss F, Goudeau A, Wands J, Sninsky J, Tiollais P, Brechot C: Transmission of hepatitis B from hepatitis-B-seronegative subjects. Lancet 1988; ii:1273-1276.

6 Hoofnagle JH, Seeff LB, Bales ZB, Zimmerman HJ: Type $B$ hepatitis after transfusion with blood containing antibody to hepatitis B core antigen. N Engl J Med 1978;22:13791383.

7 Larsen J, Hetland G, Skaug K: Posttransfusion hepatitis B transmitted by blood from a hepatitis B surface antigen-negative hepatitis B virus carrier. Transfusion 1990;30:431-432.

$>8$ Hoofnagle JH: Posttransfusion hepatitis B. Transfusion 1990;30:384-386.

-9 Allain JP, Hewitt PE, Tedder RS, Williamson LM: Evidence that anti-HBc but not $\mathrm{HBV}$ DNA testing may prevent some HBV transmission by transfusion. Br J Haematol 1999; 107:186-195.

10 Bernvil SS, Andrews V, Kuhns MC, McNamara AL: Hepatitis B core antigen antibody as an indicator of a low grade carrier state for hepatitis B virus in a Saudi Arabian blood donor population. Transfus Sci 1997;18:49-53.
11 Uchida T, Kaneita Y, Gotoh K, Kanagawa H, Kouyama H, Kawanishi T, Mima S: Hepatitis $\mathrm{C}$ virus is frequently coinfected with serum marker-negative hepatitis B virus: probable replication promotion of the former by the latter as demonstrated by in vitro cotransfection. J Med Virol 1997;52:399-405.

12 Shih CM, Lo SJ, Miyamura T, Chen SY, Lee $\mathrm{YH}$ : Suppression of hepatitis B virus expression and replication by hepatitis $\mathrm{C}$ virus core protein in HuH-7 cells. J Virol 1993;67:58235832.

13 Yoshikawa A, Tanaka T, Hoshi Y, Kato N, Tachibana K, Iizuka H, Machida A, Okamoto H, Yamasaki M, Miyakawa Y, et al: Chimeric hepatitis B virus core particles with parts or copies of the hepatitis $\mathrm{C}$ virus core protein. $\mathrm{J}$ Virol 1993;67:6064-6070.

14 Carman WF, Zanetti AR, Karayiannis P, Waters J, Manzillo G, Tanzi E, Zuckerman AJ, Thomas HC: Vaccine-induced escape mutant of hepatitis B virus. Lancet 1990;336:325-329.

15 Weinberger KM, Bauer T, Bohm S, Jilg W: High genetic variability of the group-specific a-determinant of hepatitis B virus surface antigen (HBsAg) and the corresponding fragment of the viral polymerase in chronic virus carriers lacking detectable HBsAg in serum. J Med Virol 2000;81:1165-1174.

16 Ashton-Rickardt PG, Murray K: Mutants of the hepatitis B virus surface antigen that define some antigenically essential residues in the immunodominant a region. J Med Virol 1989;29: 196-203.

17 Joller-Jemelka HI, Wicki AN, Grob PJ: Detection of HBs antigen in 'anti-HBc alone' positive sera. J Hepatol 1994;21:269-272.

18 Lindh M, Furuta Y, Ljunggren KK, Norkrans $\mathrm{G}$, Horal P: Detection of hepatitis B virus precore TAG mutant by an amplification-created restriction site method. J Infect Dis 1995;171: 194-197.

19 Zekri AR, Awlia AA, El Mahalawi H, Ismail EF, Mabrouk GM: Evaluation of blood units with isolated anti $\mathrm{HBC}$ for the presence of HBV DNA. Dis Markers 2002; 18:107-110.

20 Muller-Breitkreutz K: Results of viral marker screening of unpaid blood donations and probability of window period donations in 1997. EPFA Working Group on Quality Assurance. Vox Sang 2000;78:149-157.
21 Christensen PB, Titlestad IL, Homburg KM, Georgsen J, Kristensen T: Hepatitis B core antibodies in Danish blood donors: a surrogate marker of risk behaviour. Vox Sang 2001;81: 222-227.

22 Moncharmont P, Bourgeot C, Papon S, Duraffourg M: Antibodies against hepatitis B core antigen among blood donors. Trans Clin Biol 2000; 7:63-69.

23 Hennig H, Puchta I, Luhm J, Schlenke P, Goerg S, Kirchner H: Frequency and load of hepatitis B virus DNA in first-time blood donors with antibodies to hepatitis B core antigen. Blood 2002;100:2637-2641.

24 Kroes AC, Quint WG, Heijtink RA: Significance of isolated hepatitis B core antibodies detected by enzyme immunoassay in a high risk population. J Med Virol 1991;35:96100 .

25 Weinberger KM, Kreuzpaintner EA, Hottentrager B, Neifer S, Jilg W: Mutations in the sgene of hepatitis B virus isolates from chronic carriers with anti-HBc as the only serological marker of HBV infection; in Rizzetto M, Purcell RH, Gerin JL, Verne (eds): Viral Hepatitis and Liver Disease. Torino, Edizioni Minerva Medica, 1997, pp 138-143.

26 Noborg U, Gusdal A, Horal P, Lindh M: Levels of viraemia in subjects with serological markers of past or chronic hepatitis B virus infection. Scand J Infect Dis 2000;32:249-252.

27 Michalak TI, Pasquinelli C, Guilhot S, Chisari FV: Hepatitis B virus persistence after recovery from acute viral hepatitis. $\mathrm{J}$ Clin Invest 1994;93:230-239.

28 Prince AM, Lee DH, Brotman B: Infectivity of blood from PCR-positive, HBsAg-negative, anti-HBs-positive cases of resolved hepatitis B infection. Transfusion 2001;41:329-332.

29 Wang JT, Lee CZ, Chen PJ, Wang TH, Chen DS: Transfusion-transmitted HBV infection in an endemic area: the necessity of more sensitive screening for HBV carriers. Transfusion 2002;42:1592-1597. 